\title{
PENGEMBANGAN PERANGKAT PEMBELAJARAN FISIKA MENGGUNAKAN MODEL LEARNING CYCLE 7E UNTUK MENINGKATKAN KETERAMPILAN PENYELESAIAN MASALAH
}

\author{
Nia Erlina ${ }^{1)}$, Budi Jatmiko ${ }^{2)}$, Raharjo ${ }^{3)}$ \\ 1)Mahasiswa Program Studi Pendidikan Sains, Program Pascasarjana Universitas Negeri Surabaya \\ ${ }^{2), 3)}$ Dosen Pascasarjana Prodi Pendidikan Sains Univesrtitas Negeri Surabaya \\ E-mail: iwan.wicaksono20@gmail.com
}

\begin{abstract}
This study aims to develop physics learning material based on 7E learning cycle model veable to use improving problem solving skills. Implementation of the research has done in class X of SMAN 16 Surabaya academic year 2014/2015. Methods of data collection are validity, tests, observations, and questionnaires. The materials was developed using the modified 4D model of the design testing one group pretest-posttest design. Analysis of the significance of the increase in problem-solving skills using a paired $t$ test while to see the consistency of learning outcomes using analysis of variance. Results from this research showed: 1) the validity of learning material give results of the validation consisted of RPP value of 3.47 is valid categorized, BAS value of 3.50 is valid categorized, LKS is 3.64 categorized very valid, problem solving skills test value of 3 is valid categorized, legibility BAS is $73.90 \%$ being categorized, legibility LKS is $77.46 \%$ higher category, the level of difficulty BAS is $26.52 \%$ low categorized, the difficulty level of LKS is $26.32 \%$ low categorized; 2 ) the practicality of the learning material consist of a feasibility study learning of $93.25 \%$ is very well categorized and learning implementation constraints that arise when students understand the steps the experiment; 3) the effectiveness of learning, in terms of problem-solving skills increase significantly between before and after the learning with a high degree of improvement category; Average student activity categorized in three classes, as well as students respond positively to the learning activities, and positive student's response of learning activity. The results showed that physics learning material based on 7E learning cycle model veable to use improving problem solving skills
\end{abstract}

Key Words: 7 E learning cycle model, problem solving skills

\begin{abstract}
Abstrak: Penelitian ini bertujuan untuk mengembangkan perangkat pembelajaran fisika model learning cycle 7E yang layak digunakan untuk meningkatkan keterampilan penyelesaian masalah. Penelitian pada kelas X SMAN 16 Surabaya tahun ajaran 2014/2015. Metode pengumpulan data menggunakan validasi, tes, observasi, dan angket. Perangkat pembelajaran dikembangkan menggunakan model 4-D dengan rancangan ujicoba one group pretest-posttest design. Analisis signifikansi peningkatan keterampilan penyelesaian masalah menggunakan uji t berpasangan sedangkan untuk melihat konsistensi hasil pembelajaran menggunakan analisis varians. Hasil penelitian: 1) validitas perangkat pembelajaran dengan hasil nilai validasi terdiri dari RPP sebesar 3.47 berkategori valid, BAS sebesar 3.50 berkategori valid, LKS sebesar 3.64 berkategori sangat valid, tes keterampilan penyelesaian masalah sebesar 3 berkategori valid, keterbacaan BAS sebesar $73.90 \%$ berkategori sedang, keterbacaan LKS sebesar $77.46 \%$ berkategori tinggi, tingkat kesulitan BAS sebesar $26.52 \%$ berkategori rendah, tingkat kesulitan LKS sebesar $26.32 \%$ berkategori rendah; 2) kepraktisan perangkat pembelajaran ditinjau dari keterlaksanaan pembelajaran sebesar $93.25 \%$ berkategori sangat baik dan kendala pelaksanaan pembelajaran yang muncul saat siswa memahami langkah-langkah percobaan; 3) keefektifan perangkat pembelajaran, ditinjau dari peningkatan keterampilan penyelesaian masalah secara signifikan antara sebelum dan sesudah pembelajaran dengan derajat peningkatan berkategori tinggi; rata-rata aktivitas siswa di tiga kelas berkategori baik, serta respons siswa positif terhadap aktivitas pembelajaran. Hasil penelitian menunjukkan bahwa perangkat pembelajaran fisika model learning cycle 7E layak digunakan untuk meningkatkan keterampilan penyelesaian masalah.
\end{abstract}

Kata kunci: model learning cycle 7E, keterampilan penyelesaian masalah

\section{PENDAhuluan}

Pembukaan Undang-Undang Dasar 1945 mengamanatkan bahwa pembentukan Pemerintah Negara Indonesia yaitu antara lain untuk mencerdaskan kehidupan bangsa. Perwujudan amanat tersebut yaitu diberlakukannya Undang-Undang (UU) No. 20 Tahun
2003 tentang fungsi pendidikan nasional. Pemberlakuan UU ini diperjelas dengan visi Pendidikan nasional yaitu terwujudnya sistem pendidikan sebagai pranata sosial yang kuat dan berwibawa untuk memberdayakan semua warga negara Indonesia berkembang menjadi manusia yang berkualitas sehingga mampu dan proaktif 
menjawab tantangan zaman yang selalu berubah. Rotherham dan Willingham (2009) mengemukakan pendapatnya tentang pentingnya penguasaan kecakapan abad 21 terutama keterampilan menyelesaikan masalah. Kutipan dari The Partnership of 21st Century Skills menyatakan bahwa salah satu kategori keterampilan belajar untuk abad ke-21 adalah kemampuan menyelesaikan masalah. Tantangan yang muncul adalah menggabungkan keterampilan belajar dengan strategi belajar mengajar. Berdasarkan pendapat tersebut, kecakapan hidup perlu dilatihkan sejak dini yaitu di tingkat satuan pendidikan.

Hubungan Kurikulum dengan pendidikan menentukan kualitas pendidikan yang diharapkan. Tujuan Kurikulum 2013 adalah mempersiapkan manusia Indonesia agar memiliki keterampilan hidup sebagai pribadi dan warga negara yang beriman, produktif, kreatif, inovatif, dan afektif serta mampu berkontribusi pada kehidupan bermasyarakat, berbangsa, bernegara, dan peradaban dunia. Proses pembelajaran kurikulum 2013 diarahkan pada Standar Kompetensi Lulusan (SKL). SKL mencakup sikap, pengetahuan dan keterampilan. Kualitas hasil belajar siswa merupakan hasil dari pengalaman belajar yang dinyatakan dalam SKL. Kegiatan Belajar Mengajar (KBM) merupakan salah satu tahap yang sangat menentukan terhadap keberhasilan belajar siswa. Pembelajaran yang diperlukan adalah pembelajaran yang tidak hanya mengulang kembali ide-ide, tetapi pembelajaran yang mampu mengeksplorasi ide-ide siswa. Siswa dapat menerapkan pengetahuan yang telah diperoleh sebelumnya ke dalam situasi baru yang mengarah pada keterampilan menyelesaikan masalah (Wardhani, 2005).

Menurut Sutrisno (2006) hakikat fisika adalah sama dengan hakikat sains. Hakikat fisika adalah sebagai produk, fisika sebagai sikap, dan fisika sebagai proses.Pembelajaran yang diperlukan adalah pembelajaran yang tidak hanya mengulang kembali ideide, tetapi pembelajaran yang mampu mengeksplorasi ide-ide siswa. Mata pelajaran fisika ditujukan untuk mengembangkan keterampilan berpikir analisis induktif dan deduktif dengan menggunakan konsep dan prinsip fisika untuk menjelaskan berbagai peristiwa alam dan menyelesaikan masalah baik secara kualitatif maupun kuantitatif. Dengan demikian, siswa akan terlatih menemukan sendiri berbagai konsep secara holistik, bermakna, otentik serta aplikatif untuk kepentingan penyelesaian masalah.

Mata pelajaran fisika khususnya pada materi kalor pada kelas X SMA menuntut keterampilan memperoleh makna dari materi pembelajaran yang telah dipelajari. Kalor merupakan suatu pengertian yang tidak mudah didefinisikan dengan singkat dan tepat. Kalor yang bersifat abstrak sukar dibuktikan, tetapi dapat dirasakan keberadaannya. Perubahan suhu yang dapat dibuktikan dan dilihat melalui pengukuran menunjukkan bahwa kalor bersifat konkrit dan terdapat konsep-konsep yang harus dipahami dengan melakukan aktivitas berdasarkan pengalaman siswa sehingga menemukan pengetahuan yang diharapkan. Siswa harus menemukan sendiri dan mentransformasikan informasi konsep materi kalor sehingga mampu menyelesaikan masalah secara ilmiah berdasarkan konsep yang telah diperoleh, meningkat hasil belajar siswa, dan dapat menerapkan dalam kehidupan sehari-hari.

Hasil penelitian Programme for International Student Assessment (PISA) 2012 menunjukkan skor rata-rata mengukur kemampuan sains siswa di Indonesia adalah 382. Skor rata-rata tersebut berada pada level 2 dari 6 level yang ada yaitu siswa dapat menjelaskan konteks yang sederhana berdasarkan pengetahuan ilmiah. Hasil skor pada level tersebut memiliki kualifikasi level rendah sehingga rata-rata siswa di Indonesia diduga memiliki keterampilan dalam penyelesaian masalah yang rendah. Keterampilan dalam penyelesaian masalah yang baik diharapkan siswa mampu menggunakan pengetahuan yang diperoleh sebelumnya ke dalam situasi baru.

Observasi awal yang dilakukan di kelas X MIA 2, X MIA 3, dan $\mathrm{X}$ MIA 4 SMAN 16 Surabaya menunjukkan bahwa siswa kesulitan memahami dan menerapkan materi yang diajarkan sehingga hasil belajar fisika siswa sebagian besar masih belum mencapai Kriteria Ketuntasan Minimal (KKM) dan siswa jarang melakukan kegiatan percobaan. Observasi awal tersebut didukung dengan preliminary study pada siswa yang telah mendapatkan materi kalor dengan tujuan untuk mengukur keterampilan penyelesaian masalah siswa. Berbagai cara yang dapat digunakan untuk membantu siswa meningkatkan keterampilan penyelesaian masalah. Bransford dan Stein (dalam Schunk, 2012) memformulasikan sebuah heuristika yang mencakup penyelesaian masalah yang dikenal dengan IDEAL. Data hasil keterampilan penyelesaian masalah dari 35 siswa SMAN 16 Surabaya menunjukkan keterampilan penyelesaian masalah yang tergolong rendah meliputi: 1) identify problem $81.90 \%$; 2) define goal $71.43 \%$; 3) explore possible strategies $60.95 \%$; 4) anticipate outcomes and act 55.24\%; dan 5) look back and learn 46.67\%. Tahap identify problem telah mencapai KKM, namun keterampilan penyelesaian masalah yang rasional, lugas dan tuntas tidak sebatas pada keterampilan mengidentifikasi masalah. Berdasarkan data hasil tersebut, keterampilan penyelesaian masalah pada siswa masih perlu ditingkatkan (Erlina et al., 2015).

Fakta tersebut didukung dengan pembelajaran yang terjadi saat ini di sekolah masih banyak yang berorientasi pada upaya pengembangan dan menguji 
daya ingat siswa. Inovasi strategi dan metode pembelajaran IPA yang dilakukan guru di kelas biasanya kurang berhasil karena dalam implementasinya kurang memperhatikan karakteristik siswa, termasuk perkembangan kemampuan berpikirnya (Jeremy, 2005). Siswa kurang diberikan kesempatan untuk mengembangkan rasa ingin tahu dan kreativitas serta kurang diberikan kesempatan untuk menginterpretasikan gejala alam dari sudut prinsip ilmiah. Sanjaya (2006) berpendapat bahwa pelaksanaan pembelajaran sering berpusat pada guru. Siswa hanya menjadi objek penerima saja dan tidak memiliki kesempatan untuk mengembangkan pengetahuan sehingga kurang terampil dalam penyelesaian masalah.

Menurut Elliot et al., (2000) masalah adalah ketidaksesuaian antara kenyataan dan harapan. Belajar menyelesaikan masalah adalah belajar menggunakan metode-metode ilmiah atau berpikir secara sistematis, logis, teratur dan teliti untuk memperoleh keterampilan dan kecakapan kognitif dalam menyelesaikan masalah secara rasional, lugas, dan tuntas (Syah, 2003). Gagne (dalam Ibrahim, 2012) mengatakan bahwa keterampilan penyelesaian masalah merupakan hasil belajar yang paling tinggi. Penyelesaian masalah merupakan salah satu jenis pengolahan kognitif yang berhubungan dengan keterampilan berpikir siswa dan melibatkan penerapan konsep yang telah dimiliki sehingga menjadi indikasi adanya transfer belajar (Schunk, 2012; Snyder, 2008; Anderson, 1993). Menurut Gagne (dalam Nasution, 2003) penyelesaian masalah dapat mengembangkan keterampilan intelektual tingkat tinggi. Siswa yang belajar menyelesaikan masalah dapat belajar dua hal sekaligus, yaitu pertama siswa menemukan jawaban terhadap masalahnya dan yang kedua siswa tahu bagaimana proses/cara menyelesaikan masalahnya.

Keterampilan siswa dalam penyelesaian masalah tidak hanya dipengaruhi oleh ketidakmampuan siswa dalam menggunakan pengetahuan yang telah dimilikinya, tetapi juga dipengaruhi oleh kemampuan guru dalam KBM. Perangkat pembelajaran yang belum layak dan memadai berperan menentukan keberhasilan KBM. Pengembangan perangkat yang diduga dapat digunakan untuk meningkatkan keterampilan penyelesaian masalah siswa yaitu model learning cycle $7 E$. Learning cycle $7 E$ merupakan model pembelajaran yang terdiri dari rangkaian tahap-tahap kegiatan yang diorganisasi sedemikian rupa sehingga dapat mendukung keterampilan berfikir siswa melalui peran aktif, pengetahuan awal dan transfer belajar. Model learning cycle $7 E$ mempunyai $7 E$ fase yaitu elicit, engage, explore, explain, elaborate, evaluate, extend (Eisenkraft, 2003). Fase elaborate dan extend memberikan siswa kesempatan untuk berfikir, mencari, menemukan, menghubungkan dan menerapkan konsep pada permasalahan yang berkaitan dengan contoh pelajaran yang dipelajari sebagai gambaran aplikasi konsep yang nyata. Pemikiran siswa dapat menghubungkan konsep ke konteks yang berbeda sehingga terjadi transfer belajar. Dengan demikian, siswa dapat membangun pengetahuan di dalam benaknya sendiri dan menggunakan segenap pengetahuan yang didapat untuk menyelesaikan masalah.

Mata pelajaran fisika khususnya pada materi kalor pada kelas X menuntut keterampilan menyelesaikan masalah yang menitikberatkan pada keterlibatan siswa. Materi kalor mempunyai sifat abstrak sehingga harus dikonkritkan dengan melakukan aktivitas yang berdasakan pengalaman siswa sehingga menemukan pengetahuan yang diharapkan. Harapan dalam sebuah pembelajaran dengan menggunakan model learning cycle $7 E$ adalah siswa mampu menyelesaikan masalah secara ilmiah berdasarkan konsep yang telah diperoleh dan dapat menerapkan dalam kehidupan sehari-hari.

Berdasarkan uraian di atas, maka upaya mengembangkan perangkat pembelajaran fisika dilakukan peneliti yang berjudul "Pengembangan Perangkat Pembelajaran Fisika Menggunakan Model Learning Cycle $7 E$ untuk Meningkatkan Keterampilan Penyelesaian Masalah".

\section{METODE PENELITIAN}

Penelitian ini merupakan penelitian pengembangan karena mengembangkan perangkat pembelajaran meliputi: RPP, BAS, LKS, dan tes keterampilan penyelesaian masalah. Perangkat pembelajaran dengan model learning cycle 7E yang telah dikembangkan selanjutnya diujicobakan dalam KBM fisika di kelas pada materi kalor. Penelitian ini dilaksanakan di SMAN 16 Surabaya pada Semester Genap Tahun Pelajaran 2014/2015 diujicobakan pada 105 siswa di kelas X MIA 3, X MIA 4, dan X MIA 5.

Penelitian ini dilakukan melalui dua tahap, yaitu tahap I merupakan pengembangan perangkat pembelajaran dilanjutkan dengan ujicoba I, sedangkan tahap II merupakan implementasi perangkat pembelajaran dengan ujicoba II. Perangkat dikembangkan dengan menggunakan model 4-D. Thiagarajan, et al., (1974) menyatakan proses pengembangan perangkat model ini terdiri atas empat tahap yaitu tahap pendefinisian, perancangan, pengembangan, dan penyebaran. Pengembangan perangkat yang dilakukan peneliti hanya sampai pada tahap ketiga karena diterapkan terbatas sehingga model 4-D yang telah direduksi menjadi model 3-D yang dapat diperlihatkan pada Gambar 1. 


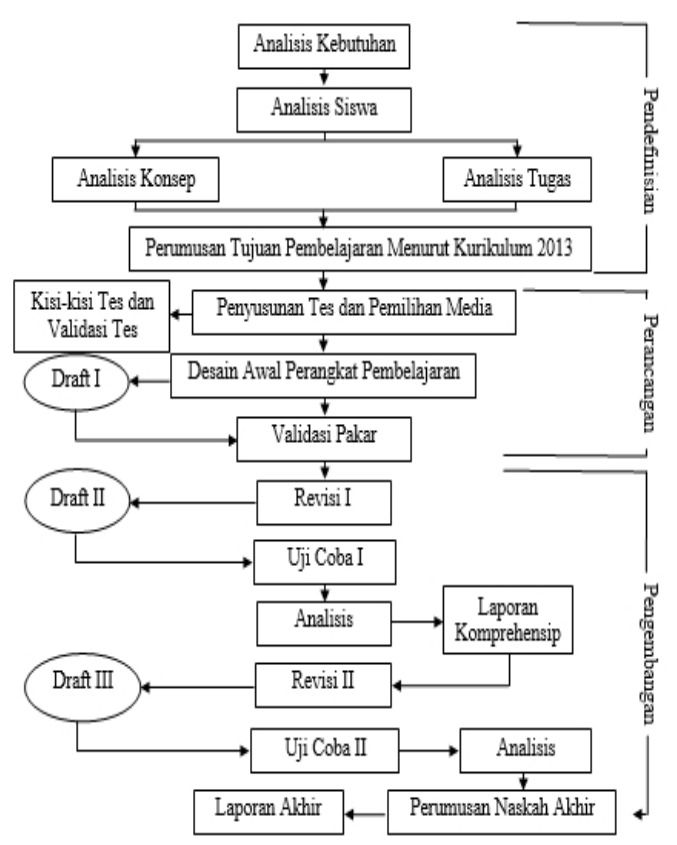

Gambar 1. Diagram Model Pengembangan Perangkat Pembelajaran (diadopsi dari Ibrahim, 2003)

Ujicoba perangkat dilakukan dengan menggunakan rancangan ujicoba one group pretest-posttest design karena menggunakan satu kelompok tanpa ada kelompok pembanding. Instrumen yang dikembangkan untuk mengumpulkan data dalam penelitian meliputi: 1) lembar validitas perangkat pembelajaran terdiri atas RPP, BAS, LKS, dan tes pemahaman konsep; 2) lembar penilaian keterbacaan BAS dan LKS; 3) lembar penilaian tingkat kesulitan BAS dan LKS; 4) lembar pengamatan aktivitas siswa; 5) lembar keterlaksanaan pembelajaran; 6) lembar kendala pelaksanaan pembelajaran; 7) angket respons siswa; dan 8) tes keterampilan penyelesaian masalah. Pengumpulan data yang dilakukan dalam penelitian ini menggunakan teknik validasi, pemberian tes, dan penyebaran angket.

Teknik analisis data dalam penelitian ini menggunakan deskriptif kuantitatif dan kualitatif. Validasi perangkat pembelajaran reliabel jika koefisien reliabilitas $\geq 75 \%$. Uji Homogenitas dilakukan pada tiga kelas replikasi untuk mengetahui varian di kelaskelas tersebut. Untuk mengetahui data sampel berasal dari populasi yang berdistribusi normal dilakukan uji normalitas menggunakan uji Chi Square. Untuk mengetahui derajad peningkatan keterampilan penyelesaian masalah dilakukan analisis statistik inferensial melalui analisis $\mathrm{N}$-gain score (nilai pretest dan posttest keterampilan penyelesaian masalah). Signifikansi pengaruh model pembelajaran yang digunakan terhadap peningkatan keterampilan penyelesaian masalah menggunakan uji $t$ sampel berpasangan. Teknik yang digunakan untuk mengetahui korelasi antara dua sampel adalah teknik korelasi product moment. Untuk menampilkan statistik rata-rata peningkatan keterampilan penyelesaian masalah dan perbedaan secara signifikan ketiga kelas dilakukan uji One-Way Anova (Sugiyono, 2008)

\section{HASIL PENELITIAN DAN DISKUSI}

\section{A. Validitas Perangkat Pembelajaran}

RPP yang dikembangkan menggunakan model learning cycle $7 E$ untuk meningkatkan keterampilan penyelesaian masalah. Nilai rata-rata validasi dari dua orang validator sebesar 3.47 berkategori valid dengan reliabilitas instrumen sebesar $85.7 \%$ sehingga RPP dapat digunakan dan reliabel.

BAS yang telah dikembangkan oleh peneliti mencakup materi Kalor meliputi: 1) Kalor; 2) Perubahan Wujud; dan 3) Perpindahan Kalor. Nilai rata-rata validasi dari dua orang validator sebesar 3.5 berkategori valid dengan reliabilitas instrumen sebesar $85.7 \%$ sehingga BAS dapat digunakan dan reliabel.

LKS yang telah dikembangkan oleh peneliti mencakup materi Kalor dan di LKS terdapat Extend yang memberikan kesempatan pada siswa mengaplikasikan konsep yang mereka dapatkan untuk melatih keterampilan penyelesian masalah . Nilai ratarata validasi dari dua orang validator sebesar 3.64 berkategori sangat valid dengan reliabilitas instrumen sebesar $85.7 \%$ sehingga LKS dapat digunakan dan reliabel.

Tes keterampilan penyelesaian masalah untuk mengukur peningkatan keterampilan penyelesaian masalah siswa menggunakan data pretest dan posttest. Tes keterampilan penyelesaian masalah materi kalor terdiri atas 15 soal pilihan ganda. Nilai rata-rata validasi dari dua orang validator sebesar 3 berkategori valid dengan reliabilitas instrumen sebesar $85.7 \%$ sehingga tes keterampilan penyelesaian masalah dapat digunakan dan reliabel. Hasil ujicoba yang dilakukan pada 15 siswa menunjukkan keterbacaan BAS sebesar $75.05 \%$ sehingga dapat dikategorikan keterbacaan sedang dan keterbacaan LKS sebesar $77.46 \%$ sehingga dapat dikategorikan keterbacaan tinggi. Tingkat kesulitan BAS sebesar $26.52 \%$ sehingga dapat dikategorikan tingkat kesulitan rendah atau mudah dipahami. Tingkat kesulitan LKS sebesar $26.32 \%$ sehingga dapat dikategorikan tingkat kesulitan rendah atau mudah dipahami.

\section{B. Kepraktisan Perangkat Pembelajaran}

Proses pembelajaran yang dikembangkan menggunakan RPP dengan model learning cycle $7 E$. Setiap fase proses KBM model learning cycle $7 E$ dapat diuraikan sebagai berikut: 1) elicit menggali pemahaman awal dalam memastikan pengetahuan awal siswa terhadap pelajaran yang akan dipelajari; 2) engage mendapatkan perhatian siswa, mendorong keterampilan berpikirnya, dan membantu mengakses pengetahuan awal; 3) explore memperoleh pengetahuan 
dengan pengalaman langsung yang berhubungan dengan konsep yang akan dipelajari; 4) explain melengkapi, menyempurnakan, dan mengembangkan konsep yang telah diperoleh siswa; 5) elaborate menerapkan konsep yang dipahami dan keterampilan yang dimiliki pada keadaan yang baru; 6) evaluate penilaian proses dan evaluasi penguasaan konsep yang diperoleh siswa; dan 7) extend mendorong untuk mencari hubungan konsep yang mereka pelajari dengan konsep lain yang sudah atau belum dipelajari.

Rata-rata keterlaksanaan RPP siswa kelas X MIA 2 sebesar 3.66 dengan kategori terlaksana sangat baik, kelas X MIA 3 sebesar 3.68 dengan kategori terlaksana sangat baik, dan kelas X MIA 4 sebesar 3.71 dengan kategori terlaksana sangat baik. Persentase keterlaksanaan RPP siswa ketiga kelas konsisten sebesar $93.25 \%$ dengan kategori terlaksana sangat baik. Instrumen keterlaksanaan yang diamati meliputi: 1) pengelolaan KBM memperoleh nilai rata-rata 3.65 sehingga sesuai dengan pendahuluan, isi, dan penutup; 2) pengelolaan waktu memperoleh nilai rata-rata 3.72 sehingga sesuai dengan alokasi waktu; dan 3) suasana memperoleh nilai rata-rata 3.78 sehingga sesuai dengan banyaknya antusias dari siswa dan guru.

Kendala dan alternatif solusi pelaksanaan pembelajaran konsisten meliputi: 1) siswa kurang terbiasa membuat hipotesis dan variabel-variabel dalam percobaan karena siswa belum terbiasa dengan LKS yang diberikan dan merupakan pembelajaran yang baru sehingga alternatif solusi yaitu menjelaskan definisi dan memberikan contoh membuat hipotesis dan variabelvariabel dalam percobaan; 2) siswa belum memahami penyajian data dalam bentuk grafik karena siswa belum terlatih membuat grafik sehingga alternatif solusi yaitu menjelaskan cara menggrafikkan data tabel hasil percobaan; 3) terdapat beberapa siswa masih kesulitan mempresentasikan hasil percobaan karena siswa belum terbiasa mempresentasikan hasil percobaan sehingga alternatif solusi yaitu guru memperjelas hasil percobaan yang perlu dipresentasikan; dan 4) siswa kurang memahami penyelesaian masalah karena siswa belum pernah dilatih keterampilan menyelesaikan permasalahan sehingga alternatif solusi yaitu menjelaskan dengan memberi salah satu permasalahan dan langkah-langkah penyelesaiannya. Secara keseluruhan hambatan yang terjadi selama penelitian bisa dicari solusinya. Sehingga penelitian bisa berjalan relatif lancar.

\section{Keefektifan Perangkat Pembelajaran}

Menurut Bransford dan Stein (dalam Rahayu dan Kartono, 2012) IDEAL problem solving yang juga sebagai indikator problem solving membentuk suatu siklus yang mempunyai langkah-langkah sebagai berikut: 1) identify problem; 2) define goal; 3) explore possible strategies; 4) anticipate outcomes and act; dan 5) look back and learn. Persentase indikator keterampilan penyelesaian masalah pretest siswa ketiga kelas menunjukkan menunjukkkan semakin tinggi tahapan indikator, nilai persentase keterampilan penyelesaian masalah semakin rendah. Hasil pretest yang rendah tersebut diduga tahap penyelesaian masalah tergolong semakin tinggi sehingga diperlukan analisis yang lebih dalam. Persentase keterampilan penyelesaian masalah posttest siswa ketiga kelas menunjukkan peningkatan yang signifikan dapat ditunjukkan dengan diagram pada Gambar 2.

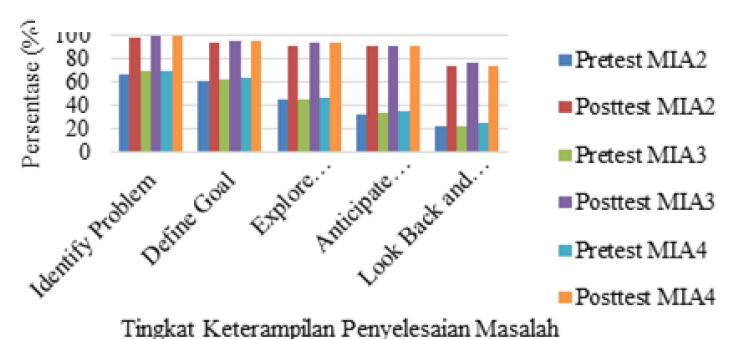

Gambar 2. Tingkat keterampilan penyelesaian masalah

Peningkatan keterampilan penyelesaian masalah di tiga kelas dipengaruhi oleh beberapa faktor meliputi: 1) proses pembelajaran model learning cycle $7 E$ yang terlaksana dengan baik dari setiap tahap terutama fase elicit adalah komponen penting dari proses pembelajaran dan fase extend yang lebih luas dari fase elaborate dimaksudkan untuk secara eksplisit mengingatkan guru bahwa sangat penting bagi siswa untuk transfer belajar; 2) siswa terdorong untuk melakukan 16 butir aktivitas yang mendukung dalam meningkatkan keterampilan penyelesaian masalah; dan 3) siswa ketiga kelas memberikan respons yang positif terhadap ketertarikan, kemutakhiran, tingkat kesulitan, model pembelajaran, tingkat kesulitan pembelajaran, dan soal keterampilan penyelesaian masalah. Peningkatan keterampilan penyelesaian masalah siswa berhubungan dengan pembelajaran model learning cycle $7 E$ yang didukung teori konstruktivis, teori perkembangan kognitif, teori motivasi. Teori-teori tersebut dapat disimpulkan, siswa harus menemukan sendiri dan mentransformasikan informasi kompleks melalui keterlibatan aktif dengan konsep dan prinsip melalui tahapan yang dicirikan oleh kemunculan dan cara mengolah informasi yang baru sehingga terdapat perkembangan intelektual berdasarkan konteks yang dialami. Siswa memiliki keterampilan penyelesaian masalah ketika mampu menerapkan pengetahuan dan ketrampilan-ketrampilan untuk mencapai tujuan Girl dkk (2002).

Hasil uji homogenitas di tiga kelas replikasi menunjukkan varian di tiga kelas adalah identik. Hasil pretest dan posttest dilakukan uji statistik normalitas 
untuk mengetahui distribusi data sehingga dapat dilakukan uji $\mathrm{t}$ sampel berpasangan. Hasil uji statistik menunjukkan ketiga kelas mempunyai data posttest yang terdistribusi normal, terdapat pengaruh yang signifikan pelaksanaan pembelajaran terhadap keterampilan penyelesaian masalah. Peningkatan keterampilan penyelesaian masalah siswa di tiga kelas menggunakan perhitungan $\mathrm{N}$-gain pada pretest dan posttest dengan kategori tinggi $g>0,70$ dan sedang $0,30<g<0,70$. Perhitungan $N$-gain siswa dari ketiga kelas konsisten menunjukkan mayoritas (33 dari 35 siswa) berada pada kategori tinggi. Hasil uji One-Way Anova menunjukkan peningkatan keterampilan penyelesaian masalah konsisten di tiga kelas memberikan hasil yang konsisten terhadap perangkat pembelajaran model learning cycle $7 E$.

Proses KBM siswa dituntut untuk aktif, pengamatan aktivitas siswa dilakukan oleh dua pengamat. Aktivitas siswa yang diamati meliputi menjawab pertanyaan terkait dengan pengetahuan awal, bertanya terkait dengan demonstrasi, mencatat, merumuskan hipotesis, mengidentifikasi variabel manipulasi, mengidentifikasi variabel kontrol, mengidentifikasi variabel respon, melakukan seluruh langkah kerja dalam pelaksanaan percobaan, mengumpulkan data, menganalisis data, menyusun kesimpulan, mempresentasikan hasil percobaan, bertanya terkait dengan hasil percobaan, berpendapat terkait dengan hasil percobaan, berdiskusi penerapan konsep, dan melakukan proses penyelesaian permasalahan yang terkait dengan konsep lain. Persentase aktivitas siswa ketiga kelas konsisten dari pertemuan pertama, kedua, dan ketiga mengalami peningkatan. Hal tersebut terjadi karena siswa mulai terbiasa dengan pembelajaran menggunakan perangkat yang telah dikembangkan.

Angket respons siswa terhadap pembelajaran model learning cycle $7 E$ untuk melihat tanggapan siswa yang meliputi: ketertarikan, kemutakhiran, tingkat kesulitan, model pembelajaran, tingkat kesulitan pembelajaran, dan soal keterampilan penyelesaian masalah. Secara keseluruhan siswa di tiga kelas konsisten memberikan respons positif terhadap pembelajaran model learning cycle $7 E$ untuk meningkatkan keterampilan penyelesaian masalah.

\section{KESIMPULAN}

\section{A. Simpulan}

Berdasarkan hasil temuan penelitian, nampak bahwa perangkat pembelajaran memenuhi kriteria valid, praktis, dan efektif sehingga dapat disimpulkan bahwa perangkat pembelajaran fisika model learning cycle $7 E$ layak digunakan untuk meningkatkan keterampilan penyelesaian masalah. Kelayakan perangkat pembelajaran memenuhi kriteria kevalidan yaitu validitas konseptual, keterbacaan maupun tingkat kesulitan BAS dan LKS, kepraktisan yaitu keterlaksanaan dan kendala pelaksanaan pembelajaran, dan keefektifan yaitu peningkatan keterampilan penyelesaian masalah, aktivitas siswa, dan respons siswa.

\section{B. Saran}

Berdasarkan penelitian ujicoba yang telah dilakukan dan hasil yang didapat, disarankan beberapa hal sebagai berikut.

1. Perlu dilakukan persiapan alat dan bahan maupun pengelolaan alokasi waktu untuk melakukan tahap explore karena siswa harus melakukan percobaan.

2. Siswa hendaknya dilatih untuk membuat hipotesis dan variabel-variabel dalam percobaan serta keterampilan penyelesaian masalah tahap Extend.

3. Perangkat pembelajaran model learning cycle $7 E$ perlu adanya penyebaran melalui sebuah proses penularan kepada para praktisi pembelajaran untuk mendapatkan masukan, koreksi, saran, penilaian, untuk menyempurnakan perangkat pembelajaran agar siap diadopsi oleh para praktisi pendidikan.

\section{DAFTAR PUSTAKA}

Bentley, M. L., et all. (2007). Teaching Constructivist Science, K-8: Nurturing Natural Investigators in the Standards-Based Classroom. Thousand Oaks. California: Corwin Press.

Eisenkraft, A. (2003). Expanding the 5 E Model A purposed 7 E model emphasizes "transfer of learning" and the importance of eliciting prior understanding. Published by the National Science Teachers Association, 1840 Wilson Blvd., Arlington, VA 22201-3000.

Elliot, S. N., Landes, N., and Taylor, J. A. (2000). Educational Psychology: effective teaching, effective Learning. Third Editional. New York: McGraw-Hill.

Erlina. N, Jatmiko. B, and Wicaksono. I. (2015). Problem Solving Skills in Learning Physics. Proceeding International Conference (2015): 427-445. ISSN: 2443-2768 Mei 2015. Pascasarjana Universitas Negeri Surabaya (UNESA), Indonesia.

Girl, T.A., Wah, L.K.M., Kang, G.Ng., and Sai, C.L. (2002). New Paradigm for Science Education. A Perspective of Teaching Problem-Solving, Creative Teaching and Primary Science Education; Singapore: Prentice Hall.

Ibrahim, M. (2012). Pembelajaran Berdasarkan Masalah: Edisi Kedua. Surabaya: Unesa University Press.

(2003). Pengembangan Perangkat Pembelajaran, Direktorat Pendidikan Lanjut 
Pertama, Dirjen Pendidikan Dasar dan Menengah, Departemen Pendidikan Nasional. Surabaya: Unesa University Press.

Jeremy, E.C. (2005). Why Eucational Innovations Fail: An Individual Difference Perspective. Cleveland State University. 33, (2) 569 - 578.

Kintsch, E., Caccamise, D., and Snyder, L. (2008), Constructivits theory and the situation model Comprehension instruction. Research-based best practices. London: The Guilford Press.

Krathwohl, D. R. and Anderson, L. W. (2001). A Taxonomy for Learning, Teaching, and Assessing: A Revision of Bloom's Taxonomy of Educational Obejctives. New York: Longman.

Nasution. (2003). Berbagai Pendekatan dalam Proses Belajar dan Mengajar. Jakarta: Bumi Aksara.

PISA. (2012). What Students Know and Can DoStudent Performance in Mathematics, Reading and Science (Volume I). London, OECD Publishing.

Rahayu and Kartono. (2012). The Effect of Mathematical Disposition toward Problem Solving Ability Based On IDEAL Problem Solver. International Journal of Science and
Research (IJSR) volume 3 ISSN (Online): 2319$7064,1316$.

Rotherham, A. J and Willingham, D. (2009). The 21st Century Skills. New York: Educational Leadership.

Schunk, Dale. (2012). Teori-Teori Pembelajaran: Perspektif Pendidikan Edisi Keenam. Yogyakarta: Pustaka Pelajar.

Sugiyono, 2008. Statistika untuk Penelitian. Bandung: Alfabeta

Sutrisno. (2006). Fisika dan Pembelajarannya. Bandung: Universitas Pendidikan Indonesia.

Syah, M. (2003). Psikologi Pengajaran. Jakarta: PT. Raja Grafindo Persada.

Thiagarajan, S. 1974. Instructional Development for Training Teacher of Exceptional Children A Sourcebook. Indiana: Indiana University.

Wardhani, Sri. (2005). Pembelajaran (Rahayu, 2012)dan Penilaian Aspek Pemahaman Konsep, Penalaran dan Komunikasi, Pemecahan Masalah. Jogjakarta: Materi Pembinaan matematika SMP di Daerah Tahun 2005 (PPPG Matematika). 